\title{
PRELIMINARY INSIGHTS INTO THE IMPLEMENTATION OF STANDARDISED IT IN FRANCHISE SYSTEMS
}

\author{
Angèle L M Cavaye \\ Department of Information Systems \\ Colin McCosker \\ Department of Marketing \\ Chad Perry \\ Department of Marketing \\ Faculty of Business \\ University of Southern Queensland \\ Toowoomba, QLD 4350, Australia
}

\begin{abstract}
The franchise context provides a rich background for studying the implementation of standardised, interlinked IT systems. Benefits of $\Pi$ implementation in franchises appear obvious, but the small business context and potential tension between the two main stakeholders (franchisor and franchisees) tend to create difficulties in the implementation process. Case study methods were used to investigate $I T$ implementation in franchise systems. Franchisee-related factors that clearly impact on implementation include perceived need for the $\Gamma T$ system, cost of the system and the level of $\Pi$ literacy among franchisees. Franchisor-related factors like coercion of franchisees and education of franchisees strongly facilitate implementation.
\end{abstract}

\section{INTRODUCTION}

This paper reports on a study investigating the implementation of standardised IT systems across franchise systems. In particular, the paper focuses on the implementation phase of the development process: on the phase when standardised IT systems are introduced to franchisees and actually installed in franchisee outlets.

The franchise context provides a rich background for studying the implementation of standardised, interlinked IT systems. Although the benefits of standardised $I T$ for franchise systems might seem obvious, actual implementation of such systems across a franchise is not a simple matter. Difficulties are created through the potential tension between franchisors and franchisees, the two stakeholders, and because of the problem of balancing and sharing the costs and benefits. Firstly, IT implementation can involve friction between franchisor and franchisee. The franchisor may want to implement standardised IT systems with links between franchisor and franchisees in order to reap franchise-wide benefits. However, the franchisee may not recognise such benefits and, in any case, may resent the franchisor gaining easy access to data about operations at the franchisee outlet.

The second difficulty concerns the trade-off between costs and benefits of IT implementation for the franchisee. All changes to business processes and all plans for IT implementation carry both benefits and costs. The need for and potential benefits of franchise-wide IT may be recognised by franchisees. However, costs of implementation may be perceived to be too high; alternatively, the introduction of new processes and new ways of working as a result of IT implementation may be perceived to pose too much difficulty.

The paper proceeds as follows. First, the research issue is explored in more detail by reporting on previous research and on preliminary empirical work for this study. Next, the research questions and case study method are described. Then, findings of the multiple case comparison are presented and discussed.

\section{IMPLEMENTATION OF STANDARDISED, INTERLINKED IT SYSTEMS IN FRANCHISES}

This section briefly explains the franchise context, outlines the major literature relevant to the study of IT systems in franchises, and describes the findings of exploratory case studies. This provides the background for the study and leads to the formulation of the research questions for this research.

\section{Franchise systems}

The main parties in a franchise system are the 'franchisor' and the 'franchisees'. The 'franchisor' is the company, person or firm granting a contractual license to another party; the 'franchisee' is the company, person or firm obtaining a license from a franchisor (Mendelsohn 1992). In this paper, the franchisor, company-owned outlets, and franchisees together comprise the 'franchise system'. 
There is both a need and a requirement for regular and continual information exchange within the franchise system. The franchisor provides initial and on-going training, informs franchisees about new and updated procedures, provides up-to-date pricing and product information, and supplies marketing information to the franchisees (Mendelsohn 1992). The franchisees are required to provide performance data to the franchisor on a regular basis. These information flows are depicted in figure 1 below.

\section{Figure 1 - Communication within a franchise system}

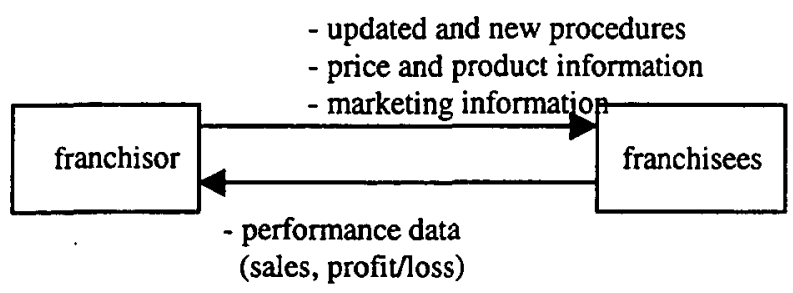

Regular information exchange among business partners implies an opportunity to use IT. Effective use of IT facilitates and speeds up information exchange; it can also lead to improved business processes on the various premises. The franchise context provides a textbook setting for use of IT between organisations.

\section{Previous research}

Two areas of IS literature are relevant to the study of IT implementation in franchise systems: the literature about inter-organisational systems and the use of IT between and among business partners and, secondly, the literature about the use of IT in small firms.

The use of IT to facilitate communication and to automate transactions between business partners has been studied for nearly 20 years. Initial papers focused on opportunities and benefits of implementing IT which links business partners (e.g. Holland and Lockett, 1994; Venkatraman, 1991). Other work highlighted factors facilitating and inhibiting implementation of electronic links between business partners (e.g. Cavaye and Cragg, 1995). Recently, interest has focused on the business opportunities provided by the Internet (McKeown and Watson, 1996) and on the adoption of electronic commerce (Kalakota and Whinston, 1996; Lawrence et al, 1998). Another strand of the literature in this area has drawn attention to the effects of power differences among business partners and to the enforced use of IT with partners who dominate the business relationship (e.g. Webster, 1995).

Since franchise systems are collections of small firms, the literature about IT adoption in small firms is relevant to this study. Cragg and King (1993), Iavocau et al (1995) and Thong and Yap (1995) identify many different factors which potentially influence adoption of IT by small firms. The factors include perceived benefit and impact of technology, pressure to adopt (from outsiders), financial and technological resources of the firm, computer literacy of the owner/manager, size and industry sector of the firm. Harrison et al (1997) focus on the executive or owner of the small firm as decisions made in small firms tend to be made unilaterally by the owner. All these issues are also likely to affect IT adoption by franchisees.

Although franchise systems provide obvious opportunities for the use of IT to link franchisor and franchisees,

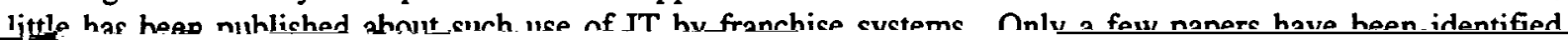


investigation. Full findings derived from the exploratory cases have been reported elsewhere (Cavaye, 1998). The main findings relating to the subject of this paper are briefly outlined below.

Implementation - an important phase of development. The focus of this paper is the implementation phase of the development process for standardised, franchise-wide IT. Case interviews showed that the $\mathrm{IT}$ development process in the context of franchise systems is very similar to the process relating to any information system that is meant to link organisations. The process consists of three clearly identifiable phases: first, a system must be acquired or developed; then, the system is implemented in individual sites; next, the systems in individual outlets are linked to the franchisor, thus forming a franchise-wide network.

Once an appropriate system has been developed, the system is implemented in franchise outlets. This implementation takes place in two stages: first, implementation of standardised systems in individual outlets; then the linking of outlets to the franchisor. The usual course of action is to implement in franchisor-owned outlets first. When the system has been shown to work well in company-owned stores, the system is implemented in franchisee outlets. Once the systems are accepted and used effectively by the franchisees, it is possible to commence linking of systems in outlets with the computer system of the franchisor at the franchise headquarters.

The implementation phase is crucial to the success of the franchise-wide IT system. Preliminary case evidence showed that benefits for the franchise system increase directly with the number of outlets using the system and linked to the franchisor. Hence, it is of utmost importance for the franchisor to ensure fast and full implementation of standardised IT systems in individual outlets.

Factors affecting the implementation phase. The franchisor has to facilitate and enable implementation of standardised, interlinked IT systems in the franchise. Franchisors need to explain the benefits of franchise-wide IT, to overcome franchisee resistance, to teach computing skills, and to train users on the specific systems to be introduced. Franchisors try to convince and educate franchisees about the value of embracing interlinked IT systems using a mix of seminars, training sessions, and face-to-face discussions with individual franchisees.

There are factors that may withhold franchisees from accepting implementation of standardised, interlinked IT. Such factors include the perception of benefits, cost of the system, level of computer literacy among franchisees, and mistrust of the franchisor. It is vital for franchisees to understand the benefits that IT can bring to their outlet and to the franchise as a whole, but not all franchisees understand these benefits. Many franchisees are interested in ways to improve the efficiency of their operations and are willing to incur some costs if it means they receive obvious, subsequent benefits. However, financial costs for full IT implementation may be significant; the cost of a sophisticated Point-of-Sale system can amount to $A \$ 40,000$ per franchisee outlet. Not all franchisees are easily persuaded to invest that much money in IT systems.

Implementation of franchise-wide IT may also be inhibited by low levels of computer literacy among franchisees. Those who are not familiar with computers fear the introduction of franchise-wide IT. In addition, there usually is a small proportion of franchisees that opposed the idea of the franchisor having full access to their operational data. Often the distrusting franchisees are those who are not operating very well.

\section{Research questions}

Early case work confirmed the importance of the implementation phase in the complete development process for franchise-wide $\Gamma T$ and identified several factors affecting the implementation of $\mathrm{IT}$ in franchisee outlets. This then formed the basis for the following research questions: 'what factors have most impact on implementation?', and 'how does the franchisor overcome franchisee resistance to implementation?".

\section{GATHERING DATA FROM MULTIPLE CASE STUDIES}

The aim of this study was to investigate use and implementation of IT as it occurs in franchise systems. There is no strong theoretical base explaining the use of IT in franchise systems. Inductive methods were needed in order to obtain information from practical settings to address the research questions. There was no intention of controlling or influencing events in individual organisations. Because there is no theoretical base and because of the wish to study contemporary events in their natural setting, the case study approach was appropriate for this study (Eisenhardt, 1989; Perry, 1998; Yin, 1994). 


\section{Criteria for case selection}

Individual cases had to be franchise systems listed in the Australian Franchise Directory. It was important to select cases where we were likely to be able to gain access. For this reason case organisations were chosen which were known to at least one of the researchers. Apart from these general criteria, individual sites were selected on the basis of dissimilarity. In this study an attempt was made to investigate a variety of firms by selecting cases which varied in terms of age, size, and industry. Cases were selected from three different states in Australia in order to avoid a possible regional bias to the findings. Table 1 summarises the case selection criteria.

Table 1 - Criteria for selecting cases in this study

\begin{tabular}{|l|l|}
\hline General criteria & listed in Australian Franchise Directory \\
\cline { 2 - 3 } & known to at least one of the researchers \\
\hline Criteria concerning & $\begin{array}{l}\text { age: mix of recent and more established franchises; young (0-5 years } \\
\text { franchise characteristics }\end{array}$ \\
\cline { 2 - 2 } & $\begin{array}{l}\text { old), medium (5-10 years old), established (over 10 years old) } \\
\text { (over 100 outlets) }\end{array}$ \\
\cline { 2 - 2 } & industry types: retail and service sectors \\
\cline { 2 - 2 } & geographical location: three different states in Australia \\
\hline
\end{tabular}

Variety in age, size, and industry type of the cases was sought because this might provide information about relevant contextual factors. It is conceivable that older franchise systems may have more difficulty implementing IT than more recent franchises, because older franchises may have more established practices and ways of working and may have franchisees who are older and, perhaps, less computer literate. With regard to size of the franchise, large franchises with a wide variety of individual franchisees may have more difficulty implementing IT in outlets than small franchises with a more homogeneous group of outlets. Relating to industry type, service franchises with few products and small outlets are likely to have more difficulty convincing franchisees to implement IT than retail franchises with a large product line since potential benefits may be more clearly recognised by retail franchisees.

\section{Data collection and analysis procedures}

An interview guide was constructed to investigate the research questions. Individual questions in the interview guide related to the benefits and costs of implementation franchise-wide IT and to the factors potentially influencing IT implementation in franchise systems. Questions were open-ended and were deliberately designed to provoke rich and lengthy answers. All data was collected within a 2 month period by visiting the headquarters of each franchise system in the case sample.

All data was collected from face-to-face interviews with individuals at each case site. Individual interviews lasted between 1 and 2 hours. Informants were members of the senior management team in each franchise system. Wherever possible relevant documentation (such as company information, IT reports, system training schedules) was collected. In several of the cases the informant provided the opportunity to view screens and links of the IT system that was the subject of the interview.

Senior management of a franchise system refers by definition to the franchisor. The franchisor informant was asked by franchisor strategy and policy; the informant was also asked about views and attitudes of franchisees. Data about franchisees was collected from the franchisors rather than from franchisees themselves. It would have been very difficult to collect information from a range of franchisees for every franchise case that we studied. For that reason we used the second-best source of information: perceptions of franchisors about their franchisees. Since this was a first investigation into the use of IT by franchise systems, the use of franchisors as the only informants was considered acceptable.

All interviews were tape-recorded and transcribed. Various authors have outlined techniques for analysing qualitative data (Miles and Huberman, 1984; Yin, 1994). These techniques include coding, tabulation, ranking and all of these have been used to analyse and present the qualitative data in this study.

Analysis was concerned with highlighting findings about each of the research questions. Firstly, data from each individual case was described and categorised; next, the data of the individual cases was combined and compared in the multiple case analysis phase. 


\section{Characteristics of the cases}

Nine franchise systems provided the case data for this study. The franchise systems were promised confidentiality and anonymity in any publications; hence they are referred to as case A, B, C, etc. Descriptive characteristics of the cases in the study are presented in Table 2.

Table 2 identifies 'age of the franchise' by noting the year in which each franchise was started. Rating of 'age' was achieved by classifying all franchises less than 5 years old as 'young', those between 5 and 10 years old as 'medium', and those older than 10 years as 'old'. The table identifies the size of each franchise case by noting the number of outlets. Rating of 'size' was obtained by categorising a franchise with less than 20 outlets as 'small', a franchise with 20 to 100 outlets as 'medium-sized', and a franchise with more than 100 outlets as 'large'. The final columns in Table 2 identify the franchises by industry and specific product supplied. The franchise sector itself identifies individual franchises as primarily retail or service based; their classification of 'retail' or 'service' franchise was used to categorise the franchises participating in this research.

Table 2 - Characteristics of franchise systems in the case sample

\begin{tabular}{|l|l|l|l|l|l|l|}
\cline { 2 - 7 } \multicolumn{2}{c|}{} & \multicolumn{2}{c|}{ AGE } & SIZE & INDUSTRY \\
\cline { 2 - 7 } \multicolumn{1}{c|}{} & $\begin{array}{l}\text { Year } \\
\text { started }\end{array}$ & Rating & $\begin{array}{l}\text { Number } \\
\text { of outlets }\end{array}$ & Rating & Type & $\begin{array}{l}\text { Specific } \\
\text { product }\end{array}$ \\
\hline Case A & 1985 & old & 41 & medium & retail & floorcovering \\
\hline Case B & 1997 & young & 16 & small & retail & car products \\
\hline Case C & 1992 & medium & 180 & large & retail & cakes \\
\hline Case D & 1995 & young & 23 & medium & retail & $\begin{array}{l}\text { household } \\
\text { products }\end{array}$ \\
\hline Case E & 1996 & young & 10 & small & service & $\begin{array}{l}\text { home } \\
\text { delivered prod. }\end{array}$ \\
\hline Case F & 1986 & old & 95 & medium & retail & books \\
\hline Case G & 1982 & old & 230 & large & service & real estate \\
\hline Case H & 1994 & young & 14 & small & service & transport \\
\hline Case I & 1986 & old & 102 & large & retail & $\begin{array}{l}\text { sports clothing } \\
\text { teguipment }\end{array}$ \\
\hline
\end{tabular}

During analysis of the case data, the three contextual factors (age, size and industry) were briefly looked at. The data did not provide sufficient information to identify clear associations between contextual factors and IT implementation.

\section{IT IMPLEMENTATION AFFECTED BY FRANCHISEE AND FRANCHISOR RELATED FACTORS}

The first research question addresses factors which may make a franchisee accept or resist standardised IT implementation in the outlet. The second research question relates to franchisor action to encourage IT acceptance by franchisees. Case findings for each of these questions are presented and discussed in this section.

\section{Franchisee-related factors influencing franchise-wide IT implementation}

Discussion with informants identified six main factors affecting franchisee acceptance of IT implementation in the outlets. 
Table 3 - Summary of factors affecting franchise-wide IT implementation

\begin{tabular}{|l|l|c|l|}
\hline Category & Individual factor & $\begin{array}{l}\text { Number of } \\
\text { cases (n=9) }\end{array}$ & $\begin{array}{l}\text { Prevalence of } \\
\text { factor }\end{array}$ \\
\hline \multirow{4}{*}{ business-related factors } & $\begin{array}{l}\text { perceived need for and business benefit of } \\
\text { franchise wide IT }\end{array}$ & 9 & v. high \\
\cline { 2 - 4 } & cost of IT system to be implemented & 8 & high \\
\cline { 2 - 4 } & time available for management/IT work & 3 & low \\
\hline \multirow{3}{*}{ IT-related factors } & level of IT literacy of franchisee & 8 & high \\
\cline { 2 - 4 } & existence of current IT systems in outlet & 5 & medium \\
\cline { 2 - 4 } & attitude towards earlier franchise-wide IT & 2 & low \\
\hline
\end{tabular}

Three of the factors identified from the case data are business-related: business benefits of IT, financial costs of IT, time available for IT work; the three other factors concern the technology itself: lack of computer knowledge, conversion difficulties when there are existing IT systems in the outlet, franchisee attitudes towards IT due to earlier experiences with IT. The business-related factors played a role in all cases; the IT-related factors were mentioned less often. Table 3 summarises the factors affecting franchise-wide IT implementation; the factors are discussed below.

Perceived need for franchise wide IT. All nine informants mentioned the importance of franchisees understanding the benefits that IT can bring to their outlet and to the franchise as a whole. In all of the 9 franchise systems the need for and understanding of business benefits played a central role in gaining franchisee acceptance of implementation of standardised IT in outlets.

Franchisees may need to be convinced that the operation of the franchise as a whole is improved by use of IT in individual outlets and by linking of systems in outlets to the franchisor. There are two stages of implementation: first, standardised IT is implemented in the outlets; then, outlets are linked to the franchisor and, sometimes, to each other. Franchisees can usually perceive the benefits of introduction of appropriate IT for the outlet; such IT implementation has a direct impact on the efficiency and effectiveness of business operations. Franchisees are less likely to acknowledge the benefits of linking with the franchisor; there may even be mistrust as to the 'secret purpose' of the franchisor in insisting on electronic linking between franchisor and franchisees.

Cost of IT system. The cost of the system varies according to the type of IT system that is proposed. One of the franchise cases (Case H) had implemented an Intranet which requires the franchisee to have a PC, modem and Intranet software; this type of system is not very expensive. On the other hand, retail franchises with many products and high turn-overs (like Case D, household products, and Case I, sports products) require that their outlets obtain one or more terminals linked to a Point-of-Sale (POS) system with multiple functionality; this type of system can cost up to $\$ 40,000$.

Apart from actual cost of the system, franchisees are particularly interested in the cost in relation to perceived benefits of using the system. One franchisor was adamant that there is no point in making franchisees pay for a system that is of no apparent benefit:

"You know, it has to be a real benefit to them for them to spend the money. We are doing the wrong thing if we talk them into spending money unnecessarily. That is going to damage the relationship down the track." (Case A)

Large outlets with high turn-overs or outlets in franchises with large product-lines readily understand the need for IT to help manage the inventory and sales functions. The immediate benefits may be less obvious to smaller outlets and to outlets with few products.

Time available for IT or other management tasks. Several of the informants mentioned that franchisees feel they do not have the time to learn a new system of working or to operate and maintain an IT system. Many franchisees are interested in being involved in the day-to-day operation of the business. In fact, a recent survey shows that $95.7 \%$ of franchisors require the franchisee to be substantially involved in the hands-on operation of the outlet; very few franchise systems allow the franchisee to be a silent partner (Franchising Australia, 1998). In some franchises time spent in the office means time lost in making money. The informant from the real estate franchise (Case G) summed it up this way:

"They are so caught up in selling, that they don't want to take time to sit down and learn to understand the IT system... Many real estate offices are not sufficiently large enough for them to be administered correctly. Real estate managers feel they don't have time to do that; to sit down and study and look at new ideas to support their work." (Case G) 
Level of computer literacy. Nearly all cases ( 8 out of the 9) made mention of a lack of computer literacy affecting the ability to implement IT in franchisee outlets. Informants discussed the fact that older franchisees in particular resisted IT implementation because they were not familiar with day-to-day computer use. Franchising Australia (1998) reports that $54.4 \%$ of franchisees are over 40 years of age with $13.4 \%$ over the age of 50 . The people in this age group have not grown up with computers and, although a proportion of these franchisees may have learnt to use computers in their own time, this group does provide the greatest difficulty for franchisors when trying to implement IT in outlets.

Existence of current IT systems in the outlets. A proportion of franchisees usually has already invested in IT systems for their outlet even if the franchisor has not in the past suggested the use of computers to enhance and facilitate operations. In retail outlets use of IT is particularly widespread. When franchisees have a current IT system in place, they are not eager to change over to a new system. This resistance is more pronounced when the cost of the system is high. Five of the cases mentioned difficulties with franchisees attributable to the existence of current IT systems in the outlets.

Attitude towards former franchise-wide IT implementation. Two of the 9 informants mentioned the effect of previous attempts to introduce standardised IT. Franchisees that have been exposed to previous, unsuccessful attempts at IT implementation have an on-going negative feeling towards franchise-wide IT. It is not easy to convince these franchisees that 'this time it is going to be different'.

Apart from identifying factors that can inhibit or facilitate IT implementation in franchises, it is important to understand their relative importance. Some factors may be more important than others; some factors may have a stronger link with implementation than other factors.

Table 4 summarises the factors and the apparent strength of their association with ease of implementation. The factors are presented in descending order of importance (as identified in the final column).

Table 4 - Franchisee-related implementation factors and link with ease of implementation

\begin{tabular}{|l|l|l|l|}
\hline Individual factors & $\begin{array}{l}\text { Effect on ease } \\
\text { of } \\
\text { implementation }\end{array}$ & Prevalence & $\begin{array}{l}\text { Link with ease } \\
\text { of } \\
\text { implementation }\end{array}$ \\
\hline $\begin{array}{l}\text { Perceived need for and business benefit of } \\
\text { franchise wide IT }\end{array}$ & positive & v. high & v. strong \\
\hline high cost of IT system & negative & high & strong \\
\hline IT illiteracy among franchisee & negative & high & strong \\
\hline time available for managementIT work & positive & medium & medium \\
\hline $\begin{array}{l}\text { Positive attitude towards earlier franchise- } \\
\text { wide IT }\end{array}$ & positive & low & medium \\
\hline Existence of current IT systems in outlet & positive & low & low \\
\hline
\end{tabular}

Analysis of case findings highlights the importance of franchisees understanding the benefits of implementing standardised IT systems in their outlets and the value of linking their IT system with the franchisor. The importance of perceived need for IT and understanding of benefits is paramount: it is a factor mentioned by all case informants and it was also identified by case informants as the factor with the most impact on implementation. If franchisees really understand the benefits and perceive a need for $I T$, then the franchisees are more likely to be willing to accept the financial cost of the system and are willing to make time available for learning and using the system.

\section{Franchisor-related factors enhancing $I T$ implementation}

Case findings show that franchisors use two main approaches to encourage implementation: education and coercion. All of the cases used a variety of ways to inform and educate franchisees; some of the cases also used coercion to ensure that franchisees implemented the appropriate IT systems.

Coercion. Franchisors can force franchisees to accept new procedures and new ways of working by writing such procedures into the franchise agreement. In this way the franchise agreement is a powerful tool to ensure that IT implementation is incorporated in outlets. When written into the franchise agreement, there is no difficulty with implementation of IT in the outlets of new franchisees. Seven of the 9 case organisations had already implemented IT in outlets. All 7 had included the purchase and use of the IT system as one of the 
conditions in the franchise agreement. Hence, new franchisees joining the franchise systems comply with the IT standards and links of the franchise.

It is more tricky to coerce existing franchisees into accepting IT. Again, franchise agreements can be used: 92 percent of franchise systems have renewable contracts for their franchisees (Franchising Australia, 1998). At the time of renewal existing franchisees would be forced into accepting implementation of standardised, interlinked IT. However, not all franchisors agree that this is an acceptable approach:

"We have found from experience that if you offer a system and they accept it, they will use it. On the other hand, if you push the system, they will not use it. Or, if they do use it, they will complain about it more than anything else." (Case $\mathrm{C}$ )

It is important to the franchisor to maintain good relationships with franchisees. Coercing reluctant franchisees into implementation of the standardised IT system can potentially harm the relationship. Franchisors are very aware of this and may choose to avoid confrontation with existing franchisees.

Education. All informants mentioned the importance of education and training of the franchisees. Support and general training is provided on a regular basis in order to maintain franchisee interest in and knowledge about the franchise business. Franchise Australia (1998) shows that Australian franchisors provide an average of 4 days of official franchise training to franchisees every year. As part of that general training the use and support of IT systems in discussed, thus placing standardised IT within the context of improving the franchise and enhancing business operations.

Once a specific system has been developed and is ready for implementation, franchisors provide specific training relating to the hardware and software to be introduced to franchise outlets. The training itself may be carried out by the franchisor, but it is more likely that this is undertaken by the consultant or software provider that will support the system.

\section{Framework of factors affecting ease of franchise-wide IT implementation}

This research identified several factors affecting standardised IT implementation in franchise systems. These factors may be categorised as factors primarily relating to the franchisee and the franchise outlet and, secondly, as factors relating to franchisor actions. Both types of factors have been discussed above. The franchiseerelated factors included perceived need for franchise-wide IT, cost of IT implementation, IT illiteracy among franchisees, time available for IT work, positive attitude towards earlier franchise-wide IT, and existence of current IT systems in franchisee outlets. The factors relating to franchisor actions included coercing franchisees into IT use and educating franchisees.

Based on the findings of this case research Figure 2 presents a research framework showing the major factors influencing ease of standardised IT implementation in franchises. Generalisability of this framework can be tested by a survey to gather data from a large number of franchise systems in Australia. The factors should also be validated in countries other than Australia.

Figure 2 - Research framework based on case findings

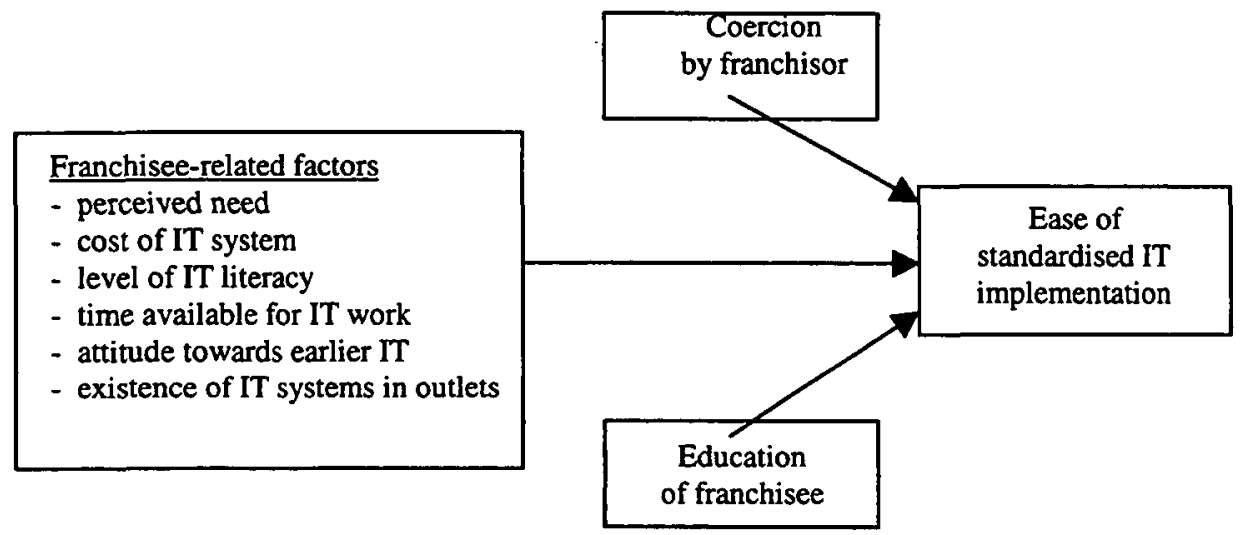

\section{CONCLUDING COMMENTS}

The objective of this study was to identify the main factors associated with ease of implementation of standardised, interlinked IT in franchise systems. Lack of existing research about IT in franchise systems implied that an in-depth study was warranted. A multiple case approach was used to collect data. 
Franchisee and franchisor related factors affecting standardised IT implementation were derived from the interview data. A major factor influencing the attitude of franchisees is the perceived need for and business benefit of franchise wide IT. This factor played a role in the implementation process of all cases and its link with ease of implementation was very strong. Two other important franchisee-related factors are cost of the IT system (a high cost is associated with difficult implementation processes) and the level of IT literacy among franchisees (lack of IT knowledge prohibits easy implementation). Coercing franchisees into IT use and education franchisees about IT were the two actions used by franchisors to enhance IT use and ease implementation of standardised IT systems.

This study is the first in-depth investigation into IT implementation to enhance communication within franchise systems. The study has several weaknesses which may be addressed in further research. Data about franchiseerelated factors was collected from franchisors; we did not discuss the findings with franchisees. A further indepth study could seek information from both franchisors and franchisees. Current findings and the suggested research framework are based on case study data. Further research could use a quantitative survey method to test the current findings in a wider setting. In addition, data could be gathered in other countries and compared with the findings in the Australian context.

\section{REFERENCES}

Cavaye A L M, (1998), "IOS in the franchising context: computerised communication between franchisor and franchisees", Proceedings of Australasian Conference of Information Systems, September, Sydney, pp 88-97

Cavaye, A.L.M. \& Cragg, P.B. (1995). Factors Contributing to Success of Customer Oriented Inter Organisational Systems. Journal of Strategic Information Systems, 4(1), pp. 13-30.

Cragg, P.B. and King, M.K. (1993). Small firm computing: motivators and inhibitors. MIS Quarterly, $17(1), p p .47-59$

Eisenhardt K. (1989). Building theories from case research. The Academy of Management Review, 14, pp.532-550

Franchising Australia (1998). A survey of franchising practices and performance, prep. by C. McCosker and L. Frazer, Franchise Council of Australia and University of Southern Queensland, Australia

Harrison D.A., Mykytyn P.P. and Rienenschneider C.K. (1997). Executive decisions about IT adoption in small business. Information Systems Research, June, 8(2), pp171-195

Holland, C.P. and Lockett, G. (1994). Strategic choice and interorganisational information systems. Proceedings of the 27th Hawaii International Conference of Systems Sciences, vol. iv, pp. 405-413

Iavocau C.L., Benbasat L. and Dexter A.A. (1995). Electronic data interchange and small organisations: adoption and impact of technology. MIS Quarterly, Dec, 19(4), pp. 465-486

Kalakota R. and Whinston, A. (1996). Frontiers of electronic commerce. Addison-Wesley, United States

Lawrence E., Corbitt B., Tidwell A., Fisher J. and Lawrence J.R. (1998). Internet Commerce. John Wiley and Sons, Brisbane, Australia

McKeown P. and Watson R. (1996). Metamorphosis - a guide to the World Wide Web and Electronic Commerce. John Wiley and Sons, New York

Mendelsohn, M. (1992). The Guide to Franchising. Casell, London.

Miles, M. B. and Huberman, A.M. (1984). Qualitative data analysis: sourcebook of new methods. Sage Publications, Beverly Hills

Nault, B.R. (1997). Mitigating underinvestment through an IT-enabled organisation form. Organisation Science, 8(3), May-June, pp. 223-234

Perry, C. (1998). Processes of a case study methodology for postgraduate research in marketing. Special joint issue of European Journal of Marketing and New Zealand Journal of Business, (forthcoming)

Poorani, A.A. (1996). Electronic Data Interchange: a strategic tool to increase franchise productivity and efficiency. Proceedings of the 10th Annual Conference of the Society of Franchising, pp. 2-16

Sen, K.C. and Lee H.L. (1994). The impact of Information Technology on the franchise decision, Proceedings of the 8th Annual Conference of the Society of Franchising, Las Vegas, Nevada.

Simeonson, R.B. and Anstadt, N. (1993). The role of computers and automated systems. In The Franchising Handbook, ed. A.J. Sherman, International Franchise Association, New York.

Thong J. and Yap C.S. (1995). CEO characteristics, organisational characteristics, and information technology adoption in small business. Omega, Aug, 23(4), pp. 429-442

Venkatraman (1991). IT induced business configuration. In The Corporation of the 1990s, ed. M. Scott Morton, Chapter 5, Oxford University Press, New York. 
Webster, J. (1995). Networks of collaboration or conflict? Electronic Data Interchange and power in the supply chain. Journal of Strategic Information Systems, 4(1), pp. 31-43

Yin R.K. (1994). Case study research: design and method, 2nd edition. Sage Publications, London 